\title{
Effects of herbicide underdoses on the vegetative development of Panicum maximum cultivars
}

\section{Efeitos da subdosagem de herbicidas no desenvolvimento vegetativo de cultivares de Panicum maximum}

\author{
Aline Guimarães CRUVINEL ${ }^{1}$; Tulio Porto GONÇALO'; Kamila Lobato MORAES²; Bruno César Silva PEREIRA²; \\ João Vitor Alves de SOUSA²; Danillo Neiva de ANDRADE1 \\ 1 Mestre, Grupo Associado de Pesquisa do Sudoeste Goiano (GAPES). E-mail: aline@gapescna.agr.br, \\ tulio.goncalo@gapescna.agr.br; danillo.neiva@gapescna.agr.br \\ 2 Engenheiro Agrônomo, Grupo Associado de Pesquisa do Sudoeste Goiano (GAPES). E-mail: kamilalobato183@gmail.com; \\ b.c.pereira@uol.com.br “Autor para correspondência”; joaovitor.alves@gapescna.agr.br
}

Recebido em: 16-02-2021; Aceito em: 16-06-2021

\begin{abstract}
The advance of intercropping has generated the need for studies that evaluate methods of suppression of forage grasses in order to not harm the development of the commercial culture. The aim of this study is to evaluate the sensitivity of forage grasses to post-emergence herbicide application. To this end, an experiment was carried out in a greenhouse using a randomized complete block design in a $4 \times 9$ factorial scheme with four replicates. The first factor consisted of the forage grasses Urochloa ruziziensis, Panicum maximum cv. BRS Tamani, P. maximum cv. BRS Quênia, and P. maximum cv. BRS Zuri. The second factor consisted of the combination of eight herbicide treatments applied at post-emergence in association with atrazine $\left(1200 \mathrm{~g}\right.$ a.i. ha- $\left.{ }^{-1}\right)$, besides a control treatment, without application. P. maximum cv. BRS Quênia was the least sensitive to post-emergence herbicide application. Tembotrione (42 and $84 \mathrm{~g}$ a.i. ha- ${ }^{-1}$ ) and mesotrione (48 and $96 \mathrm{~g}$ a.i. ha- ${ }^{-1}$ ) have potential for suppression of $U$. ruziziensis. Tembotrione ( $84 \mathrm{~g}$ a.i. ha $\left.{ }^{-1}\right)$, glyphosate $\left(200 \mathrm{~g}\right.$ a.i. ha $\left.{ }^{-1}\right)$, and nicosulfuron $\left(7.8 \mathrm{~g}\right.$ a.i. ha $\left.{ }^{-1}\right)$ have potential for suppression of the $\mathrm{cv}$. BRS Quênia, and tembotrione $\left(42 \mathrm{~g}\right.$ a.i. ha $\left.{ }^{-1}\right)$ and mesotrione $\left(96 \mathrm{~g}\right.$ a.i. ha $\left.{ }^{-1}\right)$ have potential for the suppression of BRS Tamani. The P. maximum cv. BRS Zuri presented a higher plant height, shoot dry matter, and root dry matter than the other forages evaluated. For this forage, the use of nicosulfuron herbicides at post-emergence, regardless of the dose, reduced the shoot dry matter by $70 \%$.
\end{abstract}

Additional keywords: Brachiaria ruziziensis; chemical control; phytointoxication; post-emergence.

\section{Resumo}

O avanço no cultivo de culturas consorciadas tem gerado a necessidade de estudos que avaliam métodos de supressão das gramíneas forrageiras de forma a não prejudicarem o desenvolvimento da cultura comercial. Objetivou-se, avaliar a sensibilidade de gramíneas forrageiras aos herbicidas quando aplicados em pósemergência das plantas. Para isso, foi realizado experimento em casa-de-vegetação utilizando delineamento inteiramente ao acaso em esquema fatorial $4 \times 9 \mathrm{com}$ quatro repetições. $O$ primeiro fator foi constituído das gramíneas forrageiras Urochloa ruziziensis, Panicum maximum cv. BRS Tamani, P. maximum cv. BRS Quênia e $P$. maximum cv. BRS Zuri, e o segundo fator da combinação de oito tratamentos herbicidas aplicados em pósemergência das plantas em associação com atrazina (1200 g i. a. ha-1), além da testemunha sem aplicação. $P$. maximum cv. BRS Quênia foi menos sensível a aplicação dos herbicidas em pós emergência. Tembotriona (42 e $84 \mathrm{~g}$ i. a. ha-1) e mesotriona (48 e $96 \mathrm{~g}$ i. a. ha-1) apresenta potencial para utilização na supressão de $U$. ruziziensis. Tembotriona (84 g i. a. ha-1), glifosato $\left(200 \mathrm{~g}^{\text {i. }}\right.$ a. ha- $\left.{ }^{-1}\right)$ e nicossulfuron $(7,8 \mathrm{~g}$ i. a. ha-1) apresentam potencial para supressão da forrageira Quênia, acrescido de tembotriona (42 g i. a. ha-1) e mesotriona (96 g i. a. ha-1) para BRS Tamani. P. maximum cv. BRS Zuri apresentou maior altura de plantas, massa seca da parte aérea e de raiz que as demais forrageiras avaliadas. Para essa forrageira, a utilização de herbicidas em pós-emergência nicossulfuron independente da dose reduziu cerca de $70 \%$ a massa seca da parte aérea.

Palavras-chave adicionais: Brachiaria ruziziensis; controle químico; fitointoxicação; pós-emergência.

\section{Introduction}

The use of forage grasses in intercropping systems of annual crops is considered an advantageous alternative for the sustainability of agricultural production systems (Borghi et al., 2013). The advantages are provided by the high ratio of carbon and nitrogen $(\mathrm{C} / \mathrm{N})$ of forages, increasing the straw persistence on the soil surface, which is especially desirable in warm environments with rapid decomposition of dry matter, such as in the Cerrado (Silva et al., 2019). This results in protection against insolation and raindrop impact and in the reduction of soil water evaporation and erosion. In addition, the biomass of these plants provides high contents of organic matter in the soil, contributing to nutrient cycling, 
especially in the replacement of nitrogen and carbon and in the improvement of soil properties (Ryschawy et al., 2017), besides reducing weed occurrence (Lima et al., 2014).

To ensure the success of the intercropping system, forage grasses must be well managed, so that the main crop is not harmed by plant competition. Several factors can influence grain production, including the species of grass used in the system, sowing density, location, and distribution of plants in the crop, soil fertility, sowing time, and especially the use of underdoses of herbicides for the suppression of grass growth (Almeida et al., 2017).

The genus Panicum has been gaining prominence for use as a cover crop or for forage production in integrated systems (Dias et al., 2020) mainly due to the release for commercialization of new cultivars of $P$. maximum BRS Tamani, BRS Quênia, and Zuri, which have shown positive results when used in integrated systems (Valote, 2018). Despite this, little is known regarding the suppression of growth of these cultivars when used in intercropping systems.

Generally, cultivars of $P$. maximum have a greater productive potential compared to Urochloa spp., as they have a more vigorous and deeper root system with high tolerance to water deficit and high nutrient absorption capacity at deeper soil layers (Correia et al., 2011). In addition, $P$. maximum has the characteristic of presenting its most vigorous regrowth at the beginning of the rainy season and high productive potential, combined with its erect and caespitous habit (Almeida et al., 2017). Such properties require the suppression of this grass to be assertive, so that competition between it and the main crop does not occur.

There are several results in the literature on the use of herbicide underdoses to suppress the growth of species of the genus Urochloa, in particular U. ruziziensis (R. Gem. \& C.M. Evrad) (Richetti et al., 2018). However, studies with grasses of the genus Panicum have been incipient or not very conclusive. The most used herbicides to suppress the growth of forage grasses and control narrow-leaved invasive plants intercropped with maize are mesotrione and nicosulfuron, where mesotrione has a quick action, allowing the resumption of grass growth, while nicosulfuron has a longer action, significantly reducing grass growth (Ceccon et al., 2015). However, the best dose for the suppression of the different forages used, specially for the cultivars of $P$. maximum, needs to be better studied for recommendation in intercropping systems.

Therefore, the objective of this study is to evaluate the sensitivity of species of the genus Panicum to herbicides when applied at post-emergence and tested at the recommended doses and underdoses, as well as to evaluate their efficiency in inhibiting plant growth and producing biomass for land cover.

\section{Material and methods}

The experiment was conducted in a greenhouse located at the GAPES Innovation and Technology Center, $17^{\circ} 48^{\prime} 58^{\prime \prime}$ south latitude, $51^{\circ} 03^{\prime}$ 24" longitude, and 752 m altitude, in the municipality of Rio Verde, Goiás, Brazil.

For the establishment of the experiment, a randomized complete block design (RCBD) in a factorial scheme $(4 \times 9)$ with four replicates was used. The first factor consisted of four species of forage grasses, namely: Urochloa ruziziensis, Panicum maximum cv. BRS Tamani, Panicum maximum cv. BRS Quênia, and Panicum maximum cv. Zuri. The second factor consisted of eight concentrations of four herbicides applied at post-emergence, besides the treatment without application (control). All herbicide treatments received $1200 \mathrm{~g}$ a.i. ha-1 of atrazine. Treatments with the herbicides glyphosate, mesotrione, nicosulfuron, and tembotrione and their respective evaluated doses are listed in Table 1.

The planting of the species was carried out on February 20, 2020 in experimental units consisting of black-colored pots with volumetric capacity of $3.00 \mathrm{dm}^{-3}$ containing a mixture of soils in the ratio of two parts of fine sand and one part of clayey soil ( $45 \%$ clay). After planting, the plots were thinned in order to standardize treatments and conditions of interference between plants, with a total of five plants per pot remaining at 25 days after planting.

At 40 days after sowing (DAS), the postemergence herbicide application was conducted using a $\mathrm{CO}_{2}$ backpack sprayer equipped with a $3.0 \mathrm{~m}$ boom and XR 110015 spray nozzles spaced $0.5 \mathrm{~m}$ apart, with an application rate of $150 \mathrm{~L} \mathrm{ha}^{-1}$.

The percentage of phytotoxicity was evaluated at 7,21 , and 35 days after application (DAA) of the herbicide treatments. For this, a visual score in percentage in which 0 represents absence of symptoms and $100 \%$ represents plant death was assigned (SBCPD, 1995). Plant height was evaluated before the application of treatments (41 days after sowing) and 7 days after application (DAA) of herbicide treatments. For this, the five plants of each pot were measured from the neck to the end of the panicle using a graduated ruler.

At 35 DAA, the plants were cut close to the ground to determine shoot dry matter and the roots were washed to determine root dry matter. These samples were placed in paper bags and maintained in a forced air circulation oven for a period of 72 hours at a temperature of $65^{\circ} \mathrm{C}$, being subsequently weighed using a precision scale.

Data were subjected to analysis of variance using the software ASSISTAT (Silva \& Azevedo, 2016). When significant effects were found, the treatment means were compared by Tukey test for the first factor (species) and by the Scott-Knott test for the second factor (herbicides), both at a 5\% significance level. 
Table 1 - List of herbicides applied at post-emergence of forage grass species.

\begin{tabular}{lcc}
\hline \multirow{2}{*}{ Herbicides $^{*}$} & \multicolumn{2}{c}{ Dose } \\
\cline { 2 - 3 } & $\mathrm{g}$ or L c. p. ha ${ }^{-1}$ & $\mathrm{~g} \mathrm{a}$. i. ha ${ }^{-1}$ \\
\hline Control & 0.1 & - \\
Tembotrione & 0.2 & 42 \\
Tembotrione & 0.2 & 84 \\
Glyphosate & 0.4 & 100 \\
Glyphosate & 0.1 & 200 \\
Mesotrione & 0.2 & 48 \\
Mesotrione & 0.1 & 96 \\
Nicosulfuron & 0.2 & 7.8 \\
Nicosulfuron & 0.6 \\
\hline
\end{tabular}

${ }^{*}$ In all treatments containing herbicides, atrazine was added (dose of 3.0 L c. p. ha ${ }^{-1}$ or $1200 \mathrm{~g}$ a.i. ha-1).

\section{Results and discussion}

Table 2 presents the summary of the analysis of variance for the characteristics evaluated as a function of the different forage grasses and herbicides applied at post-emergence. In the evaluation of plant height before application, as expected, significant effect was only observed for the factor species. The other variables (phytotoxicity, plant height after application, shoot dry matter, and root dry matter) presented significant effect on the interaction species versus herbicide. These results demonstrate the importance of evaluating the influence of each forage species after herbicide application separately.

Table 2 - Summary of the analysis of variance (calculated $F$ values) for the variables phytotoxicity, plant height before and after application (PHB and PHA, respectively), shoot dry matter (SDM), and root dry matter (RDM) as a function of different forage grass species and herbicides.

\begin{tabular}{|c|c|c|c|c|c|c|c|c|}
\hline \multirow{3}{*}{ Source of variation } & \multirow{3}{*}{ DF } & \multicolumn{7}{|c|}{$F$ values } \\
\hline & & \multicolumn{3}{|c|}{ Phytotoxication } & \multirow{2}{*}{ PHB } & \multirow{2}{*}{$\mathrm{PH}$} & \multirow{2}{*}{ SDM } & \multirow{2}{*}{ RDM } \\
\hline & & 7 DAA & $21 \mathrm{DAA}$ & 35 DAA & & & & \\
\hline Species (S) & 3 & $33.9^{* *}$ & $59.6^{\star *}$ & $133.5^{\star \star}$ & $3.4^{*}$ & $126.9^{* *}$ & $44.4^{* *}$ & $20.0^{* *}$ \\
\hline Herbicide $(\mathrm{H})$ & 2 & $39.8^{* *}$ & $155.1^{\star \star}$ & $332.3^{\star *}$ & $2.3^{\text {ns }}$ & $12.9^{* *}$ & $34.1^{* *}$ & $16.3^{\star *}$ \\
\hline $\mathrm{S} \times \mathrm{H}$ & 4 & $3.8^{* *}$ & $9.8^{* *}$ & $35.1^{\star *}$ & $1.2^{\mathrm{ns}}$ & $2.9^{* *}$ & $2.2^{* \star}$ & $4.2^{* *}$ \\
\hline Residue & 48 & - & - & - & - & - & - & - \\
\hline CV (\%) & & 30.9 & 22.1 & 16.3 & 13.5 & 25.9 & 31.9 & 53.5 \\
\hline
\end{tabular}

DAA = days after application; $n s,{ }^{*}, * *$ : not significant and significant at 5 and $1 \%$ probability level by the $\mathrm{F}$ test, respectively.

Before application, the forage $P$. maximum cv. BRS Zuri presented the highest plant height (up to $53 \%$ higher than the others), followed by $P$. maximum cv. BRS Quênia and finally the species $P$. maximum cv. BRS Tamani and $U$. ruziziensis (Table 3). Understanding the early development of the forage plant is essential for making management recommendations. Fast growing cultivars such as BRS Zuri must be well managed, so that competition with the commercial species does not occur. On the positive side, the larger size is directly related to the dry matter content that the plant will provide, to nutrient cycling, increased organic matter, and decreased soil evaporation, possibly also providing a higher stocking rate for animals and higher yields for subsequent crops (Borges et al., 2014; Costa \& Queiroz, 2017). On the other hand, the smaller size of $U$. ruziziensis and $P$. maximum cv. BRS Quênia may indicate greater ease of management in the intercropping system. 
Table 3 - Plant height before application of Urochloa ruziziensis, Panicum maximumcv. BRS Tamani, P. maximum cv. BRS Quênia, and $P$. maximum cv. BRS Zuri.

\begin{tabular}{lc}
\hline Species & Plant height before application $(\mathbf{c m})$ \\
\hline U. ruziziensis & $13.88 \mathrm{c}$ \\
P. maximum cv. BRS Quênia & $25.86 \mathrm{~b}$ \\
P. maximum cv. BRS Tamani & $15.79 \mathrm{c}$ \\
P. maximum cv. BRS Zuri & $38.96 \mathrm{a}$ \\
\hline
\end{tabular}

Means followed by different lowercase letters differ significantly by the Tukey test $(p<0.05)$.

Table 4 shows the results of phytotoxicity of different forage grasses after post-emergence herbicide applications. In the first phytotoxicity evaluation, carried out 7 days after application (DAA), in general, the forage $P$. maximum cv. BRS Quênia was less sensitive to postemergence herbicide application. For $U$. ruziziensis, the use of glyphosate and nicosulfuron at the recommended doses (200 and $15.6 \mathrm{~g}$ a.i. ha ${ }^{-1}$, respectively) provided a phytotoxicity greater than $90 \%$, demonstrating that they are not interesting alternatives for use in intercropping systems to suppress this forage. The high sensitivity of $U$. ruziziensis plants to a higher dose of glyphosate is related to the rapid translocation of the herbicide to the site of action, which may be greater in a situation of plant stress. Thus, lower doses than those recommended should be indicated to avoid plant death (Matias et al., 2019). The herbicides that presented an intermediate level of phytotoxicity against U. ruziziensis were tembotrione (42 and $84 \mathrm{~g}$ a.i. $\mathrm{ha}^{-1}$ ) and nicosulfuron at a dose of $7.8 \mathrm{~g}$ a.i. ha-1.

Table 4 - Phytotoxicity of Urochloa ruziziensis, Panicum maximum cv. BRS Quênia, P. maximum cv. BRS Tamani, and $P$. maximum cv. BRS Zuri as a function of post-emergence herbicide application.

\begin{tabular}{|c|c|c|c|c|c|c|}
\hline Phytotoxicity & Herbicide & Dose (g a. i. ha-1) & U. ruziziensis & $\begin{array}{c}\text { BRS } \\
\text { Quênia } \\
\end{array}$ & $\begin{array}{c}\text { BRS } \\
\text { Tamani }\end{array}$ & BRS Zuri \\
\hline \multirow{9}{*}{7 DAA } & Control & - & $0.0 \mathrm{aD}$ & $0.0 \mathrm{aB}$ & $0.0 \mathrm{aD}$ & $0.0 \mathrm{aB}$ \\
\hline & Tembotrione & 42 & $70.0 \mathrm{aB}$ & $15.0 \mathrm{bB}$ & $62.5 \mathrm{aB}$ & $57.5 \mathrm{aA}$ \\
\hline & Tembotrione & 84 & $75.0 \mathrm{abB}$ & $50.0 \mathrm{bA}$ & $83.7 \mathrm{aA}$ & $61.2 \mathrm{abA}$ \\
\hline & Glyphosate & 100 & $33.2 \mathrm{abC}$ & $11.2 \mathrm{bB}$ & $46.2 \mathrm{aC}$ & $48.7 \mathrm{aA}$ \\
\hline & Glyphosate & 200 & $95.0 \mathrm{aA}$ & $55.0 \mathrm{bA}$ & $92.5 \mathrm{aA}$ & $52.5 \mathrm{bA}$ \\
\hline & Mesotrione & 48 & 20.0 bC & $17.5 \mathrm{bcB}$ & $43.7 \mathrm{abC}$ & $58.7 \mathrm{aA}$ \\
\hline & Mesotrione & 96 & $25.0 \mathrm{bcC}$ & $20.0 \mathrm{cB}$ & $63.7 \mathrm{aB}$ & $52.5 \mathrm{abA}$ \\
\hline & Nicosulfuron & 7,8 & $65.0 \mathrm{aB}$ & $52.5 \mathrm{aA}$ & $72.5 \mathrm{aB}$ & $46.2 \mathrm{aA}$ \\
\hline & Nicosulfuron & 15,6 & $93.7 \mathrm{aA}$ & $32.5 \mathrm{cA}$ & $97.5 \mathrm{aA}$ & $61.2 \mathrm{Ba}$ \\
\hline \multirow{9}{*}{$21 \mathrm{DAA}$} & Control & - & $0.0 \mathrm{aD}$ & $0.0 \mathrm{aC}$ & $0.0 \mathrm{aD}$ & $0.0 \mathrm{aD}$ \\
\hline & Tembotrione & 42 & $38.7 \mathrm{aC}$ & $26.2 \mathrm{aB}$ & $27.5 \mathrm{aC}$ & $40.0 \mathrm{aB}$ \\
\hline & Tembotrione & 84 & $50.0 \mathrm{aB}$ & $45.0 \mathrm{abA}$ & $32.5 \mathrm{bC}$ & $42.5 \mathrm{abB}$ \\
\hline & Glyphosate & 100 & $57.5 \mathrm{aB}$ & 27.5 bB & $17.5 \mathrm{bC}$ & $30.0 \mathrm{bC}$ \\
\hline & Glyphosate & 200 & $100.0 \mathrm{aA}$ & $42.5 \mathrm{cA}$ & $75.0 \mathrm{bB}$ & $60.0 \mathrm{bA}$ \\
\hline & Mesotrione & 48 & $5.0 \mathrm{bD}$ & $1.2 \mathrm{bC}$ & $1.2 \mathrm{bD}$ & $25.0 \mathrm{AC}$ \\
\hline & Mesotrione & 96 & $40.0 \mathrm{aC}$ & $7.5 \mathrm{cC}$ & $25.0 \mathrm{abc}$ & $21.2 \mathrm{bcC}$ \\
\hline & Nicosulfuron & 7,8 & $97.5 \mathrm{aA}$ & $45.0 \mathrm{cA}$ & 70.0 bB & $55.0 \mathrm{bcA}$ \\
\hline & Nicosulfuron & 15,6 & $100.0 \mathrm{aA}$ & $55.0 \mathrm{bA}$ & $97.5 \mathrm{aA}$ & 47.5 bB \\
\hline \multirow{9}{*}{35 DAA } & Control & - & $0.0 \mathrm{aE}$ & $0.0 \mathrm{aF}$ & $0.0 \mathrm{aF}$ & $0.0 \mathrm{aF}$ \\
\hline & Tembotrione & 42 & $16.2 \mathrm{bD}$ & $17.5 \mathrm{bE}$ & $31.2 \mathrm{aC}$ & $37.5 \mathrm{aB}$ \\
\hline & Tembotrione & 84 & $41.2 \mathrm{aC}$ & $36.2 \mathrm{abC}$ & $37.5 \mathrm{abB}$ & $30.0 \mathrm{bB}$ \\
\hline & Glyphosate & 100 & $65.0 \mathrm{aB}$ & $26.2 \mathrm{bD}$ & $15.0 \mathrm{cE}$ & $26.2 \mathrm{bC}$ \\
\hline & Glyphosate & 200 & $100.0 \mathrm{aA}$ & $41.2 \mathrm{bB}$ & $42.5 \mathrm{bB}$ & $43.7 \mathrm{bA}$ \\
\hline & Mesotrione & 48 & $3.7 \mathrm{abE}$ & $1.2 \mathrm{bF}$ & $1.2 \mathrm{bF}$ & $13.7 \mathrm{aD}$ \\
\hline & Mesotrione & 96 & $16.2 \mathrm{abD}$ & $6.2 \mathrm{bF}$ & $22.5 \mathrm{aD}$ & $20.0 \mathrm{aD}$ \\
\hline & Nicosulfuron & 7.8 & $100.0 \mathrm{aA}$ & $42.5 \mathrm{bcB}$ & $36.2 \mathrm{cB}$ & $50.0 \mathrm{bA}$ \\
\hline & Nicosulfuron & 15.6 & $100.0 \mathrm{aA}$ & 53.7 bA & $95.0 \mathrm{aA}$ & $46.2 \mathrm{bA}$ \\
\hline
\end{tabular}

DAA = days after application; Means followed by different lowercase letters in the rows differ significantly by the Tukey test $(p<0.05)$. Means followed by different uppercase letters in the columns differ by the Scott-Knott test $(p<0.05)$.

For the forage grass cultivars BRS Quênia and BRS Tamani, the herbicides tembotrione $\left(84 \mathrm{~g}\right.$ a.i. ha-1 ${ }^{-1}$, glyphosate at a dose of $200 \mathrm{~g}$ a.i. ha-1 ${ }^{-1}$, and nicosulfuron at a dose of $15.6 \mathrm{~g}$ a.i. ha-1 provided the highest levels of 
phytotoxicity at 7 DAA, besides nicosulforon at a dose of $7.8 \mathrm{~g}$ a.i. ha-1 for the cultivar BRS Quênia. Although these two cultivars belong to the same species and presented similar behavior in relation to herbicides, it is important to highlight that the level of phytotoxicity observed for the cultivar BRS Tamani was very high for the aforementioned herbicides (above 80\%), not being interesting alternatives for the suppression of this forage. This result may be related to the characteristic of the cv. BRS Tamani of presenting narrower and longer leaves than BRS Quênia, which may contribute to a greater ease of control (Tesk et al., 2020). On the other hand, for the forage cultivar BRS Zuri, all the herbicides used promoted a similar phytotoxicity (46.2 to $61.2 \%$ ), being superior to the control without application.

In the subsequent phytotoxicity evaluations at 21 and 35 DAA, there was a decrease in herbicide phytotoxicity except for nicosulfuron, especially at the dose of $15.6 \mathrm{~g}$ a.i. ha-1. In this sense, this herbicide should be used with caution, as nicosulfuron has a longer action that significantly reduces grass growth (Ceccon et al., 2015).

The herbicides glyphosate (200 g a.i. ha $\left.{ }^{-1}\right)$ and nicosulfuron (7.8 and $15.6 \mathrm{~g}$ a.i. ha ${ }^{-1}$ ) promoted the death of $U$. ruziziensis plants, demonstrating their high sensitivity to these herbicides. Thus, their use is not interesting for the suppression of this species in intercropping. In this case, the herbicides tembotrione at the doses of 42 and $84 \mathrm{~g}$ a.i. ha ${ }^{-1}$, besides glyphosate at a dose of $100 \mathrm{~g}$ a.i. ha- ${ }^{-1}$ and mesotrione at a dose of $96 \mathrm{~g}$ a.i. ha-1, promoted intermediate levels of phytotoxicity (between 38.7 to $57.5 \%$ ) at $21 \mathrm{DAA}$, proving to be interesting alternatives for the suppression of $U$. ruziziensis. The suppression of plants by the use of the herbicide combined with the shading provided by the commercial crop used in the intercropping may be able to mitigate the effects of competition between the forage and the crop, maximizing the benefit of intercropping (Ceccon et al., 2015).

For the cultivar BRS Quênia at 21 DAA, the herbicides that promoted the greatest phytotoxicity were also tembotrione (84 $\mathrm{g}$ a.i. ha-1), glyphosate (200 $\mathrm{g}$ a.i. ha 1), and nicosulfuron (7.8 and $15.6 \mathrm{~g}$ a.i. ha-1), with phytotoxicity values between 42.5 to $55 \%$. The phytotoxicity values decreased in the evaluation at 35 DAA, demonstrating the recovery power of this cultivar, which has the characteristic of presenting high tillering and a large amount of leaves (Jank et al., 2017). The other herbicides used, regardless of the evaluation, were not able to satisfactorily suppress this forage grass, with phytotoxicity values below $27 \%$ for all evaluations.

The phytotoxicity values decreased considerably in the evaluation at 21 DAA for the cultivar BRS Tamani (except for nicosulfuron). The herbicides that promoted intermediate phytotoxicity for this cultivar and that have the potential to be used in suppression were tembotrione (84 g a.i. ha-1), glyphosate (100 g a.i. $\mathrm{ha}^{-1}$ ), and mesotrione (96 $\mathrm{g}$ a.i. ha-1). Matthias et al. (2019) also observed that intermediate doses of glyphosate (from 58 to $116 \mathrm{~g}$ a.i. $\mathrm{ha}^{-1}$ ) have the potential to be used in the suppression of BRS Tamani. Regarding the forage cultivar BRS Zuri, all herbicides applied at post-emergence presented potential to be used in the suppression of this cultivar, with levels of phytotoxicity lower than $60 \%$ in the evaluation at 21 DAA and lower than $50 \%$ in the evaluation at 35 DAA.

For all herbicides used, the cultivar Zuri had the highest plant height, shoot dry matter, and root dry matter (Table 5). This result should be carefully observed, since the higher height and dry matter of this cultivar can provide greater competition with the species of commercial interest in an intercropping system. Furthermore, the herbicides were not able to suppress the height of this forage when compared to the control, regardless of the herbicide used. The cultivar BRS Zuri has the characteristic of fast growth and recovery even under adverse conditions, a fact that contributed to the lack of difference in herbicide treatments in relation to the control (Silva et al., 2020). However, the use of the herbicide nicosulfuron at post-emergence (7.8 and $15.6 \mathrm{~g}$ a.i. ha ${ }^{-1}$ ) was able to promote a reduction of up to $70 \%$ in shoot dry matter content, while glyphosate and mesotrione at the doses of 100 and $48 \mathrm{~g}$ a.i. ha-1, respectively, promoted a reduction of approximately $30 \%$.

For $U$. ruziziensis, the use of tembotrione (42 and $84 \mathrm{~g}$ a.i. ha-1) and mesotrione (48 and $96 \mathrm{~g}$ a.i. ha- ${ }^{-1}$ ) were able to reduce the shoot dry matter of the forage from 30 to $54 \%$. However, they did not influence the root dry matter and can be used in intercropping systems for the suppression of this forage. The other herbicides reduced the shoot dry matter from 75 to $100 \%$ and considerably reduced the root dry matter, indicating a high sensitivity of the species. Thus, its use to suppress the growth of $U$. ruziziensis is not recommended. These results corroborate those observed by Adegas et al. (2011), who concluded that tembotrione and mesotrione promote weed control in the intercropping system of maize with $U$. ruziziensis, besides producing phytotoxic effects on forage.

The use of tembotrione (84 $\mathrm{g}$ a.i. ha-1), glyphosate (200 g a.i. ha-1), and nicosulfuron (7.8 g a.i. $\mathrm{ha}^{-1}$ ) reduced the plant height and root dry matter of cultivar BRS Quênia, besides reducing its shoot dry matter by approximately $50 \%$. In addition to the herbicides aforementioned, tembotrione and mesotrione at doses of 42 and $96 \mathrm{~g}$ a.i. ha ${ }^{-1}$, respectively, were also efficient in suppressing the growth of cultivar BRS Tamani, demonstrating a greater sensitivity of this cultivar. These results will contribute to the search for viable alternatives to suppress the growth of $P$. maximum cultivars in the intercropping system, attenuating the effect of forage competition, which will contribute to the maximum exploitation of the commercial crop. 
Table 5 - Plant height, shoot dry matter, and root dry matter of the species Urochloa ruziziensis, Panicum maximum cv. BRS Tamani, P. maximum cv. BRS Quênia, and P. maximum cv. BRS Zuri as a function of post-emergence herbicide application.

\begin{tabular}{|c|c|c|c|c|c|c|}
\hline & Herbicide & Dose (g a. i. ha-1) & U. ruziziensis & $\begin{array}{c}\text { BRS } \\
\text { Quênia } \\
\end{array}$ & $\begin{array}{c}\text { BRS } \\
\text { Tamani } \\
\end{array}$ & BRS Zuri \\
\hline \multirow{9}{*}{ Height (cm) } & Control & - & $27.9 \mathrm{bA}$ & $32.4 \mathrm{bA}$ & $28.5 \mathrm{bA}$ & $47.4 \mathrm{aA}$ \\
\hline & Tembotrione & 42 & $13.1 \mathrm{bB}$ & $32.1 \mathrm{aA}$ & $16.4 \mathrm{bA}$ & $39.1 \mathrm{aA}$ \\
\hline & Tembotrione & 84 & $7.7 \mathrm{cB}$ & $21.3 \mathrm{bB}$ & $9.3 \mathrm{cB}$ & $36.1 \mathrm{aA}$ \\
\hline & Glyphosate & 100 & $21.7 \mathrm{bA}$ & $25.4 \mathrm{bB}$ & $20.7 \mathrm{bA}$ & $42.5 \mathrm{aA}$ \\
\hline & Glyphosate & 200 & $2.8 \mathrm{cB}$ & 23.9 bB & $7.7 \mathrm{cB}$ & $39.6 \mathrm{aA}$ \\
\hline & Mesotrione & 48 & $21.8 \mathrm{bA}$ & $28.7 \mathrm{abA}$ & $23.5 \mathrm{abA}$ & $33.4 \mathrm{aA}$ \\
\hline & Mesotrione & 96 & $18.1 \mathrm{bA}$ & 20.3 bB & $17.0 \mathrm{bA}$ & $33.1 \mathrm{aA}$ \\
\hline & Nicosulfuron & 7.8 & $2.8 \mathrm{cB}$ & $28.8 \mathrm{bA}$ & $19.6 \mathrm{bA}$ & $41.7 \mathrm{aA}$ \\
\hline & Nicosulfuron & 15.6 & $8.6 \mathrm{bcB}$ & $19.9 \mathrm{bB}$ & $0.0 \mathrm{cB}$ & $37.7 \mathrm{aA}$ \\
\hline \multirow{9}{*}{ Shoot dry matter $(\mathrm{g})$} & Control & - & $6.9 \mathrm{bA}$ & $5.8 \mathrm{bA}$ & $4.8 \mathrm{bA}$ & $10.1 \mathrm{aA}$ \\
\hline & Tembotrione & 42 & $3.7 \mathrm{abB}$ & $3.9 \mathrm{abB}$ & $2.5 \mathrm{bB}$ & $5.5 \mathrm{aC}$ \\
\hline & Tembotrione & 84 & $3.2 \mathrm{aB}$ & $2.9 \mathrm{aC}$ & $2.4 \mathrm{aB}$ & $4.5 \mathrm{aC}$ \\
\hline & Glyphosate & 100 & $1.7 \mathrm{cC}$ & $4.0 \mathrm{bB}$ & $4.4 \mathrm{bA}$ & $7.1 \mathrm{aB}$ \\
\hline & Glyphosate & 200 & $0.1 \mathrm{bC}$ & $2.6 \mathrm{aC}$ & $2.6 \mathrm{aB}$ & $4.7 \mathrm{aC}$ \\
\hline & Mesotrione & 48 & $4.8 \mathrm{abB}$ & $5.7 \mathrm{abA}$ & $4.1 \mathrm{bA}$ & $6.5 \mathrm{aB}$ \\
\hline & Mesotrione & 96 & $3.6 \mathrm{abB}$ & $4.2 \mathrm{abB}$ & 3.1 bB & $5.4 \mathrm{aC}$ \\
\hline & Nicosulfuron & 7.8 & $0.2 \mathrm{bC}$ & $2.8 \mathrm{aC}$ & $1.7 \mathrm{abB}$ & $3.5 \mathrm{aD}$ \\
\hline & Nicosulfuron & 15.6 & $0.2 \mathrm{bC}$ & $1.4 \mathrm{abC}$ & $0.4 \mathrm{bC}$ & $2.9 \mathrm{aD}$ \\
\hline \multirow{9}{*}{ Root dry matter (g) } & Control & & $10.1 \mathrm{bA}$ & $15.6 \mathrm{bA}$ & $12.1 \mathrm{bA}$ & $43.9 \mathrm{aA}$ \\
\hline & Tembotrione & 42 & $5.9 \mathrm{aA}$ & $12.7 \mathrm{aA}$ & $7.9 \mathrm{aA}$ & $11.7 \mathrm{aB}$ \\
\hline & Tembotrione & 84 & $5.8 \mathrm{aA}$ & $7.7 \mathrm{aB}$ & $7.3 \mathrm{aA}$ & $9.7 \mathrm{aB}$ \\
\hline & Glyphosate & 100 & $3.8 \mathrm{aB}$ & $12.1 \mathrm{aA}$ & $10.3 \mathrm{aA}$ & $11.0 \mathrm{aB}$ \\
\hline & Glyphosate & 200 & $1.0 \mathrm{aB}$ & $5.5 \mathrm{aB}$ & $6.9 \mathrm{aA}$ & $8.4 \mathrm{aB}$ \\
\hline & Mesotrione & 48 & $9.8 \mathrm{aA}$ & $13.7 \mathrm{aA}$ & $10.7 \mathrm{aA}$ & $13.2 \mathrm{aB}$ \\
\hline & Mesotrione & 96 & $6.2 \mathrm{aA}$ & $10.1 \mathrm{aA}$ & $8.9 \mathrm{aA}$ & $9.1 \mathrm{aB}$ \\
\hline & Nicosulfuron & 7.8 & $1.2 \mathrm{bB}$ & $10.7 \mathrm{aA}$ & $3.5 \mathrm{abB}$ & $7.7 \mathrm{abB}$ \\
\hline & Nicosulfuron & 15.6 & $1.0 \mathrm{aB}$ & $5.8 \mathrm{aB}$ & $1.1 \mathrm{aB}$ & $6.2 \mathrm{aB}$ \\
\hline
\end{tabular}

Means followed by different lowercase letters in the rows differ significantly by the Tukey test $(p<0.05)$. Means followed by different uppercase letters in the columns differ by the Scott-Knott test $(p<0.05)$.

\section{Conclusions}

The forage P. maximum cv. BRS Quênia was less sensitive to post-emergence herbicide application.

The use of tembotrione (42 and $84 \mathrm{~g}$ a.i. ha-1) and mesotrione (48 and $96 \mathrm{~g}$ a.i. ha-1) has potential for use in the suppression of $U$. ruziziensis.

The herbicides that presented potential for suppression of the cultivars BRS Quênia and BRS Tamani were tembotrione $(84 \mathrm{~g}$ a.i. ha-1), glyphosate (200 g a.i. ha-1), and nicosulfuron (7.8 g a.i. ha-1), besides tembotrione and mesotrione at the doses of 42 and $96 \mathrm{~g}$ a.i. ha ${ }^{-1}$, respectively, for BRS Tamani.

Regardless of the herbicide treatment, the $P$. maximum $\mathrm{CV}$. BRS Zuri presented the highest plant height, shoot dry matter, and root dry matter. For this forage, the use of nicosulfuron herbicides (7.8 and 15.6 $\mathrm{g}$ a.i. ha $\left.{ }^{-1}\right)$ at post-emergence reduced the shoot dry matter by up to $70 \%$.

\section{Acknowledgement}

To the Grupo Associado de Pesquisa do Sudoeste Goiano (GAPES) for funding the research.

\section{References}

Adegas FS, Voll E, Gazziero DLP (2011) Manejo de plantas daninhas em milho safrinha em cultivo solteiro ou consorciado à braquiária ruziziensis. Pesquisa Agropecuária Brasileira 46(10):1226-1233.

Almeida REM, Gomes CM, Lago BC, Oliveira SM, Junior CP, Favarin JL, Costa RV (2017) Métodos de implantação do consórcio entre milho e cultivares de Panicum spp. Para sistemas de integração lavoura pecuária. Embrapa pesca e aquicultura - Palmas, Tocantins.

Borges WLB, Freitas RS, Mateus GP, Sá ME, Alves MC (2014) Supressão de plantas daninhas utilizando plantas de cobertura do solo. Planta Daninha 32(4), 755-763. doi: 10.1590/S0100-83582014000400010

Borghi E, Crusciol CAC, Mateus GP, Nascente AS, Martins PO (2013) Intercropping time of corn and palisadegrass or guineagrass affecting grain yield and forage production. Crop Science 53(4), 629-636. doi: 10.2135/cropsci2012.08.0469 
Ceccon G, Concenço G, Borghi E, Duarte PA, Silva AF, Kappes C, Almeida REM (2015) Implantação e manejo de forrageiras em consórcio com milho safrinha. Embrapa Agropecuária Oeste. Dourados - MS.

Correia NM, Leite MB, Daniel B (2011) Efeito do consórcio de milho com panicum maximum na comunidade infestante e na cultura da soja em rotação. Planta Daninha 29(3), 545-555, 2011. doi: 10.1590/S0100-83582011000300008

Costa JAA, Queiroz HP (2017) Régua de manejo de pastagens. Campo Grande: Embrapa Gado de Corte, p. 7.

Dias MBC, Costa KAP, Severiano EC, Bilego UO, Furtini Neto AE, Almeida DP, Brand SC, Vilela L (2020) Brachiaria and Panicum maximum in an integrated crop-livestock system and a second-crop maize system in succession with soybean. The Journal of Agricultural Science 2(1), 1-12. doi: 10.1017/S0021859620000532

Jank L, Andrade CMS, Barbosa RA, Macedo MCM, Valerio JR, Verzignassi JR, Zimmer AH, Fernandes CD, Santos MF, Resende RMS (2017) O capim-BRS Quênia (Panicum maximum Jacq.) na diversificação e intensificação das pastagens. Brasília, DF.

Lima SF, Timossi PC, Almeida DP, Silva UR (2014) Palhada de braquiária ruziziensis na supressão de plantas daninhas na cultura da soja. Revista Agrarian, v. 7, n. 26, p. 541-551, 2014.

Matias ML, Goncalves VO, Braz GBP, Andrade CLL, Silva AG, Barroso ALL (2019) Uso de subdoses de glyphosate na supressão de espécies forrageiras consorciadas com milho. Científica 47(4), 380. doi: 10.15361/1984-5529.2019v47n4p380-387

Richetti A, Pezarico CR, Ceccon G, Sunakozawa CM, Saldanha WR (2018) Consórcio milho com Brachiaria ruziziensis. Embrapa Agropecuária Oeste. Dourados MS.
Ryschawy J, Martin G, Moraine M, Duru M, Therond O (2017) Designing crop-livestock integration at different levels: toward new agroecological models? Nutrient Cycling Agroecosystems 108(1), 5-20. doi: 10.1007/s10705-016-9815-9

Silva, AG, Assis RL, Oliveira CAA, Ferreira CJB, Teixeira IR, Almeida KL, Carmo EL (2019) Variabilidade dos atributos físicos do solo e dinâmica da palhada em sistema integração lavoura-pecuária no Cerrado. Revista Brasileira de Milho e Sorgo 18(3), 429-440. doi: 10.18512/1980-6477/rbms.v18n3p429-440

Silva, EB, Carneiro, MSS, Furtado, RN, Lopes, MN, Braga, MM (2020) Chemical composition of Panicum maximum 'BRS Zuri' subjected to levels of salinity and irrigation depths. Revista Ciência Agronômica 51(1), e20175997. doi: 0.5935/1806-6690.20200016

Silva FASE, Azevedo CAV (2016) The Assistat Software Version 7.7 and its use in the analysis of experimental data. African Journal of Agricultural Research 11(39), 3733-3740. doi: 10.5897/AJAR2016.11522

SBCPD (Sociedade Brasileira Da Ciência Das Plantas Daninhas) -(1995) Procedimentos para instalação, avaliação e análise de experimentos com herbicidas.

Tesk CRM, Cavalli J, Pina DS, Pereira DH, Pedreira CGS, Jank L, Sollenberger LE, Pedreira BC (2020) Herbage responses of Tamani and Quênia guineagrasses to grazing intensity. Agronomy Journal 112(3), 2081-2091. doi: 10.1002/agj2.20189

Valote PD (2018) Acúmulo de Forragem e Estrutura dos Pastos das Cultivares BRS Zuri e BRS Quênia (Megathyrsus maximus) Sob Manejo Rotacionado. UFRRJ (dissertação de mestrado) 